TRADE VERSUS INVESTMENT

LIBERALIZATION

\author{
James R. Markusen
}

Working Paper 6231 


\section{TRADE VERSUS INVESTMENT LIBERALIZATION}

James R. Markusen

Working Paper 6231

http://www.nber.org/papers/w6231

\section{NATIONAL BUREAU OF ECONOMIC RESEARCH 1050 Massachusetts Avenue \\ Cambridge, MA 02138 \\ October 1997}

This work has been supported by a grant from the National Science Foundation to the National Bureau of Economic Research. This paper is part of NBER's research program in International Trade and Investment. Any opinions expressed are those of the author and not those of the National Bureau of Economic Research.

(C) 1997 by James R. Markusen. All rights reserved. Short sections of text, not to exceed two paragraphs, may be quoted without explicit permission provided that full credit, including $\mathbb{C}$ notice, is given to the source. 
Trade versus Investment Liberalization

James R. Markusen

NBER Working Paper No. 6231

October 1997

JEL Nos. F12, F23

International Trade and Investment

ABSTRACT

Despite several theoretical contributions and considerable informal empirical evidence to the contrary, a notion that trade and investment are substitutes persists in trade policy analysis. This paper considers the liberalization of commodity trade versus liberalization allowing direct investment versus the two together. For a relatively skilled-labor-scarce economy, I show that trade and investment liberalization are quite different, and that the two together are in a sense complements. The intuition may be that direct investment provides such a country with crucial inputs (knowledge-intensive producer services) without which the country cannot effectively exploit its abundant factors in certain industries.

\author{
James R. Markusen \\ Department of Economics \\ University of Colorado \\ Boulder, CO 80309-0256 \\ and NBER \\ markusen@spot.colorado.edu
}




\section{Introduction}

Many developing countries have embarked on a path of liberalization during the last decade. Such liberalizations are accompanied by many uncertainties, both of theoretical and very practical natures. There are important issues about what to liberalize and in what order to do so. Many of these issues are macro, monetary, and institutional in nature while others relate to trade and longterm direct investment. The latter is the "stuff" of trade theory, yet trade economists have not participated much in the discussion to the best of my knowledge. In particular, we have not had too much to say about trade versus direct investment liberalization, which forms to topic of this paper.

It may be the case that trade theory continues to be heavily influenced by the ideas first put forward by Mundell, that trade in goods and factors are substitutes (Mundell, 1957, Jones, Coelho, and Easton, 1986). In the Heckscher-Ohlin framework, goods trade can indeed be thought of as just embodied trade in factor services. This was shown to be a very special property of the HeckscherOhlin model in contributions by Markusen (1983), Wong (1986), and Neary (1995) among others. Trade in factors as well as trade in goods may be necessary to exhaust the gains from trade and introducing factor trade may increase the volume of commodity trade in a wide variety of circumstances. In both a welfare and in a volume-of-trade sense, trade in goods and factors may be complements.

Parallel work in the 1980's focussed on direct investment and on how the activities of multinational firms differed from "portfolio" capital flows or more generally the flows of physical factors of production in a traditional neoclassical general-equilibrium model. The theory of the multinational has a long history, but early attempts to reconcile it with trade theory include Markusen (1984) and Helpman (1984). The former focussed on horizontal investments in which a firm undertakes the same activities in several countries, while the latter focussed on vertical investments in which the production process is decomposed by stages according to factor intensities. But in both 
cases, firms export the services of firm-specific assets to foreign production facilities. It is not very clear from this early work how such flows differ from the flow of physical factors of production, but conceptually they are distinct. Multinationals export services produced from physical factors, rather than (or in addition to) those factors themselves. Furthermore, these knowledge-intensive services may have a joint (or "public") input characteristic, in that they can yield the same services in multiple locations simultaneously.

The accumulation of evidence from the last fifteen years or so suggests that it is important to examine more closely the relationship between trade and direct investment, especially with respect to this substitutes/complements issue. One reason is that continued developments of the theory by trade and international business economists emphasizes that direct investments are motivated by firmspecific business opportunities and not by some general return to physical factors. Second, there has been a substantial rise in both trade and direct investment since the early 1970's, with direct investment growing substantially faster than trade. Third, direct investment has been concentrated among the high-income countries, even more so than trade, with some moderation of this effect in the 1990's (almost $40 \%$ of the direct investment to developing countries went to China alone however). These stylized facts suggest that (a) direct investment is not motivated primarily by tradebarrier-avoidance, and (b) not motivated primarily by factor-endowment/price differences. Both results cast significant doubt on any treatment which sees direct investment as more or less the same thing as portfolio/physical factor flows.

The purpose of this paper is to consider the relationship between trade and investment liberalization. The focus will be on host/developing countries and how they are affected asymmetrically between the liberalization of trade, direct investment, and both together. Production in the advanced sector, and real and relative factor prices receive most of the attention.

The model has two goods ( $\mathrm{X}$ and $\mathrm{Y}$ ), two factors ( $\mathrm{L}$, unskilled labor and S, skilled labor), and 
two countries (h and $\mathrm{f}$ ). $\mathrm{Y}$ is a composite competitive sector producing with constant returns and perfect competition. $\mathrm{X}$ has increasing returns at both the firm and the plant level. Production may be geographically fragmented into a skilled-labor-intensive, "headquarters" activity that includes R\&D, management, finance, and marketing, and a less-skill-intensive production activity. Yet the latter is assumed to be more skilled-labor-intensive than composite $\mathrm{Y}$ production.

There are six possible firm "types", each defined as a configuration of plants and headquarters locations. Single plant national firms (type-n) have one plant with headquarters and plant in the same location, one firm type for each country of location. Two-plant horizontal multinationals (typem) have plants in both countries, with the country of headquarters defining the firm type. Finally, there are single-plant vertical multinationals (type-v) which have their single plant and headquarters in different countries. The term "regime" denotes the types of firms active in equilibrium. ${ }^{1}$

First, I derive the equilibrium regime over a large parameter space (the world Edgeworth box) in which the countries differ in size and in relative endowments. This is done for different levels of transport costs and with and without the assumption of a prohibitive ban on direct investment.

Then the paper turns to a consideration of a small sub-space in which there is a large, skilledlabor-abundant country (h) and a smaller, unskilled-labor abundant country (f). There is an initial equilibrium (referred to as HP - high protection), in which trade costs are very high and direct investment is banned. Then there is an trade liberalization equilibrium (TL) in which trade costs go to zero, but the investment ban remains. An investment liberalization scenario (IL) drops the investment barrier, but retains high trade costs. Finally, a combined liberalization of both trade and investment is analyzed (FF - free-free).

\footnotetext{
${ }^{1}$ In previous work with Venables $(1995,1996 a, b)$, we used a four-firm-type model: there were no vertical multinationals. While this was appropriate for certain purposes, it misses an important aspect of the problem for developing countries, more the focus of this paper, which may be hosts to substantial vertical investment.
} 
In the initial high-protection scenario (HP), type-n firms dominate, but with most of them headquartered in country h. Trade-liberalization (TL) drives all the national firms out of country $\mathrm{f}$, and has the expected Heckscher-Ohlin effect of raising the price of the abundant factor in each country. Investment liberalization (IL) leads, however, to the establishment of two-plant type-m multinationals. Country $f$ loses its national firms, but gains branch plants of type-m firms headquartered in country $h$. The latter are less skilled-labor intensive than the former, because the branch plants require no skilled-labor for headquarters activities. Under the various assumptions of the model, investment liberalization expands production sufficiently in country $f$ that it draws more resources from the $\mathrm{Y}$ sector than are released from the exiting domestic national firms. Production not only increases in country $f$, but the real and relative price of skilled labor rises, therefore rising in both countries.

The full liberalization scenario (FF) also leads to the introduction of multinationals, but now they are type-v firms with their headquarters in country $h$ and their single plant in country $\mathrm{f}$. These firms export to country h, reversing the pattern of commodity trade under high protection, investment liberalization, and trade liberalization alone. Under the various assumptions, production of $\mathrm{X}$ is much higher in country $f$ in FF than in any of the other scenarios, and the real and relative wage of skilled labor is higher than under either HP or TL. Interestingly, the pro-competitive effects on firm scale and efficiency also lead to the result that the real wage of unskilled labor in country $f$ is higher than under the other scenarios.

Not all of these results are robust, and I will try to point out their dependence on key parameters throughout the paper. But the purpose here is to be suggestive, and in particular to note how the liberalization of trade and direct investment may lead to quite different effects, and how the combination of the two leads to quite different outcomes than either alone. 
The following two Tables present some evidence to document stylized facts noted above. The first Table notes that, although there was a slowdown in the early 1990 's, direct investment flows and stocks and sales by foreign affiliates of multinationals have continued to grow significantly faster than GDP and trade flows. Table 2 notes the concentration of both inward and outward direct investment among the developed countries. Inward investment to the developing countries and to Central and Eastern Europe (CEE) grew significantly in the 1990s, although most of the increase was accounted for by China.

$\underline{\text { Table } 1}$

Annual growth rate $(\%)$, all countries 1986-1990 1991-1994

FDI inflows

24.7

12.7

FDI stocks

19.8

8.8

Sales of foreign affiliates

17.4

5.4

GDP at factor cost

10.8

4.3

Exports of goods and non-factor

14.3

3.8

services

$\underline{\text { Table } 2}$

FDI inflows and outflow, share in total

\begin{tabular}{lllllll} 
Year & \multicolumn{2}{c}{$\begin{array}{c}\text { Developed } \\
\text { in }\end{array}$} & out & \multicolumn{2}{c}{ Developing } & \multicolumn{2}{c}{ CEE } \\
in & out & in & out \\
$1983-1987$ & 76 & 95 & 24 & 5 & 0 & 0 \\
$1988-1992$ & 78 & 93 & 21 & 7 & 1 & 0 \\
1993 & 62 & 85 & 35 & 15 & 3 & 0 \\
1994 & 59 & 83 & 39 & 17 & 3 & 0 \\
1995 & 65 & 85 & 32 & 15 & 4 & 0
\end{tabular}

Source: UNCTAD World Investment Report, 1996. 


\section{2. $\quad$ Model Structure}

The model has two countries ( $h$ and $f$ ) producing two homogeneous goods, $\mathrm{Y}$ and $\mathrm{X}$. There are two factors of production, L (unskilled labor), and S (skilled labor). L and S are mobile between industries but internationally immobile. $\mathrm{Y}$ will be used as numeraire throughout the paper.

Subscripts $(i, j)$ will be used to denote the countries (f,h). The output of $\mathrm{Y}$ in country $\mathrm{i}$ is a CES function, identical in both countries. The production function for $\mathrm{Y}$ is

$$
Y_{i}=\left(a L_{i y}^{\varepsilon}+(1-a) S_{i y}^{e}\right)^{1 / \varepsilon} \quad i=h, f
$$

where $\mathrm{L}_{\mathrm{iy}}$ and $\mathrm{S}_{\mathrm{iy}}$ are the unskilled and skilled labor used in the $\mathrm{Y}$ sector in country $\mathrm{i}$. The elasticity of substitution $(1 /(1-\epsilon))$ is set at 3.0 in the simulation runs reported later in the paper.

Good $\mathrm{X}$ is produced with increasing returns to scale by imperfectly-competitive, Cournot firms. There are both firm-level (arising from joint inputs such as R\&D) and plant-level scale economies. There is free entry and exit of firms, and entering firms choose their "type". The term "regime" denotes the set of firm types active in equilibrium. There are six firm types, defined as follows.

Type $\mathrm{m}_{\mathrm{h}}$ - horizontal multinationals which maintain plants in both countries, headquarters is located in country $h$.

Type $\mathrm{m}_{\mathrm{f}}{ }^{-} \quad$ horizontal multinationals which maintain plants in both countries, headquarters is located in country $\mathrm{f}$.

Type $n_{h}-\quad$ national firms that maintain a single plant and headquarters in country $h$. Type $h$ firms may or may not export to country $f$.

Type $\mathbf{n}_{\mathrm{f}}-\quad$ national firms that maintain a single plant and headquarters in country $\mathrm{f}$. Type f firms may or may not export to country $h$.

Type $v_{h}$ - vertical multinationals that maintain a single plant in country $f$, headquarters in country $h$. Type $v_{h}$ firms may or may not export to country $h$.

Type $\mathrm{v}_{\mathrm{f}}{ }^{-} \quad$ vertical multinationals that maintain a single plant in country $\mathrm{h}$, headquarters in country $f$. Type $v_{f}$ firms may or may not export to country $f$. 
Factor-intensity assumptions are crucial to the results that will be derived below. These are guided by what I believe are some empirically relevant assumptions. (1) headquarters activities are more skilled-labor intensive than production plants (including both plant-specific fixed costs and marginal costs). This obviously implies that an "integrated" type-n firm with a headquarters and plant in the same location is more skilled-labor intensive than a plant alone. (2) We assume that a plant alone (no headquarters) is more skilled labor intensive than the composite $\mathrm{Y}$ sector. This is much less obvious, but some evidence suggests that this is probably true for developing countries: branch plants of foreign multinationals are more skilled-labor intensive than the economy as a whole (Slaughter, 1996, gives data on the labor-force composition of US multinationals' home operations versus their affiliates abroad). Assumptions on the skilled-labor intensity of activities are therefore:

\section{$\underline{\text { Activities }}$ \\ [headquarters only] $>$ [integrated $\mathrm{X}]>$ [plant only] $>[\mathrm{Y}]$}

(3) We assume that two-plant type-m firms are more skilled labor intensive than single-plant type-n or type-v firms. Two-plant firms are assumed to need additional skilled labor in the source country in order to manage the overseas facility, as well as needing some skilled labor in the host country branch-plant as well. Single-plant type-n or type-v firms are assumed to use unskilled labor in shipping costs if they supply the market in which the plant is not located. Assumptions on the skilledlabor intensity of firm types are therefore:

\section{Firm Types}

[type-m firms] $>$ [type-v and type-n firms]

The assumption that some of the additional skilled labor needed by type-m firms must be located in the source country then allows us to also rank a given firm's operations within a particular country. A locally-headquartered type-v firm is, for example, the most skilled-labor intensive since it has only a headquarters in the country. Next comes a locally-headquartered type-m firm (needed additional 
skilled labor to manage the subsidiary) followed by a local type-n firm (headquarters and plant), etc. The skilled-labor-intensity ranking of a particular firm's overall activities within a country is therefore:

\section{Operations within a Country}

[local type-v firm] $>$ [local type-m firm] $>$ [local type-n firm] $>$

[plant of foreign type-m or type-v firm] $>[\mathrm{Y}]$

Superscripts (n,v,m) will be used to designate a variable as referring to national firms, vertical multinationals, and horizontal multinational firms respectively. $\left(\mathrm{m}_{\mathrm{i}}, \mathrm{v}_{\mathrm{i}}, \mathrm{n}_{\mathrm{i}}\right)$ will also be used to indicate the number of active $\mathrm{m}, \mathrm{v}$, and $\mathrm{n}$ firms based in country $\mathrm{i}$. Hopefully, it will always be clear from the context what is being represented (e.g., $n_{i}$ as a variable in an equation always refers to the number of national firms in country i). Important notation in the model is as follows.

$p_{i} \quad-\quad$ price of $X($ in terms of $Y)$ in country $i(i=h, f)$

$w_{i} \quad$ - wage of unskilled labor in country $i$

$z_{i} \quad-\quad$ wage of skilled labor in country $i$

c - marginal cost of X production in units of $L$ (both countries, all firm types)

$\tau \quad$ - transport cost for $\mathrm{X}$ in units of $\mathrm{L}$ (same in both directions)

$\mathrm{M}_{\mathrm{i}} \quad$ - Income of country $\mathrm{i}$.

$X_{\mathrm{ij}}^{k} \quad$ - Sales of: $\quad$ a type-k firm $\quad(k=n, v, m)$ based in country $\mathrm{i}$

sales in market $j \quad(i, j=h, f)$

$e_{i j}^{k} \quad-\quad$ Markup of: a type-k firm $(k=n, v, m)$ based in country $i$

sales in market $j \quad(i, j=h, f)$

$\mathrm{G}^{\mathrm{k}} \quad$ - $\quad$ Fixed costs of a type-k firm in units of unskilled labor (where relevant: $\quad$ subscript $1=$ headquarters' country subscript 2 = host country)

$\mathrm{F}^{\mathrm{k}} \quad$ - $\quad$ Fixed costs of a type-k firm in units of skilled labor (where relevant: subscript $1=$ headquarters' country subscript 2 = host country) 
A national firm undertakes all its production in its base country, so the cost function of one national firm in country $i$ is given by

$$
w_{i} L_{i}^{n}+z_{i} S_{i}^{n}=w_{i}\left[c X_{i i}^{n}+(c+\tau) X_{i j}^{n}+G^{n}\right]+z_{i} F^{n}, \quad i, j=h, f, \quad i \neq j
$$

c, $\tau, F^{\mathrm{n}}$ and $\mathrm{G}^{\mathrm{n}}$ are identical across countries.

A horizontal multinational based in country $i$ has sales in country $j, X_{i j}^{m}$. It operates one plant in each country incurring fixed costs, $\left(G_{1}^{m}, F_{1}^{m}\right)$ in its base country, and fixed costs $\left(G_{2}^{m}, F_{2}^{m}\right)$ in country $j$. Sales are met entirely from local production not trade. $L_{i j}^{m}\left(S_{i j}^{m}\right)$ denotes a country $\mathrm{i}$ horizontal multinational firm's demand for unskilled (skilled) labor in country j. A firm type $\mathrm{m}_{\mathrm{i}}$ thus has a cost function

$$
w_{i} L_{i i}^{m}+w_{j} L_{i j}^{m}+z_{i} S_{i i}^{m}+z_{j} S_{i j}^{m}=w_{i}\left[c X_{i i}^{m}+G_{1}^{m}\right]+w_{j}\left[c X_{i j}^{m}+G_{2}^{m}\right]+z_{i} F_{1}^{m}+z_{j} F_{2}^{m}
$$

Similarly, a vertical multinational based in country $i$ (plant in country j) has sales in country $\mathrm{j}, \mathrm{X}_{\mathrm{ij}}^{\mathrm{v}} \cdot \mathrm{L}_{\mathrm{ij}}^{\mathrm{v}}\left(\mathrm{S}_{\mathrm{ij}}^{\mathrm{v}}\right)$ denotes a country i vertical multinational firm's demand for unskilled (skilled) labor in country $\mathrm{j}$. A firm type $\mathrm{v}_{\mathrm{i}}$ has a cost function

$$
w_{j} L_{i j}^{v}+z_{i} S_{i i}^{v}+z_{j} S_{i j}^{v}=w_{j}\left[c X_{j i}^{m}+(c+\tau) X_{j i}^{v}+G^{v}\right]+z_{i} F_{1}^{v}+z_{j} F_{2}^{v}
$$

Let $\bar{L}_{i}$ and $\bar{S}_{i}$ denote the total labor endowments of country $i$. Adding labor demand from $n_{i}$ national firms, $v_{i}$ and $v_{j}$ vertical multinationals, and $m_{i}$ and $m_{j}$ horizontal multinationals gives country i factor market clearing:

$$
\begin{gathered}
\bar{L}_{i}=L_{i y}+n_{i} L_{i}^{n}+m_{i} L_{i i}^{m}+m_{j} L_{j i}^{m}+v_{j} L_{j i}^{v} \\
\bar{S}_{i}=S_{i y}+n_{i} S_{i}^{n}+m_{i} S_{i i}^{m}+m_{j} S_{j i}^{m}+v_{i} S_{i i}^{v}+v_{j} S_{j i}^{v}
\end{gathered}
$$


In equilibrium, the $\mathrm{X}$ sector makes no profits so country $\mathrm{i}$ income, denoted $\mathrm{M}_{\mathrm{i}}$, is

$$
M_{i}=w_{i} \bar{L}_{i}+v_{i} \bar{S}_{i} \quad i=h, f
$$

$\mathrm{p}_{\mathrm{i}}$ denotes the price of $\mathrm{X}$ in country $\mathrm{i}$, and $\mathrm{X}_{\mathrm{ic}}$ and $\mathrm{Y}_{\mathrm{ic}}$ denote the consumption of $\mathrm{X}$ and $\mathrm{Y}$. Utility of the representative consumer in each country is Cobb-Douglas,

$$
U_{i}=X_{i c}^{\alpha} Y_{i c}^{1-\alpha}, \quad X_{i c} \equiv n_{i} X_{i i}^{n}+n_{j} X_{j i}^{n}+m_{i} X_{i i}^{m}+m_{j} X_{j i}^{m}+v_{i} X_{i i}^{v}+v_{j} X_{j i}^{v}
$$

giving demands

$$
X_{i c}=\alpha M_{i} / p_{i}, \quad Y_{i c}=(1-\alpha) M_{i}
$$

Equilibrium in the $\mathrm{X}$ sector is the solution to a complementarity problem. First, there are marginal revenue - marginal cost inequalities, associated with outputs per firm. These are given by:

$$
\begin{array}{lr}
p_{i}\left(1-e_{i i}^{n}\right) \leq w_{i} c & \left(X_{i i}^{n}\right) \\
p_{j}\left(1-e_{i j}^{n}\right) \leq w_{i}(c+\tau) & \left(X_{i j}^{n}\right) \\
p_{i}\left(1-e_{i i}^{m}\right) \leq w_{i} c & \left(X_{i i}^{m}\right) \\
p_{j}\left(1-e_{i j}^{m}\right) \leq w_{j} c & \left(X_{i j}^{m}\right) \\
p_{i}\left(1-e_{j i}^{v}\right) \leq w_{i} c & \left(X_{j i}^{v}\right) \\
p_{i}\left(1-e_{i i}^{v}\right) \leq w_{j}(c+\tau) & \left(X_{i i}^{v}\right)
\end{array}
$$

In a Cournot model with homogeneous products, the optimal markup formula is given by the firm's market share divided by the Marshallian price elasticity of demand in that market. In our model, the price elasticity is one (see equation (8)), reducing the firm's markup to its market share. 
This gives, (also using demand equations (8)),

$$
e_{i j}^{k}=\frac{X_{i j}^{k}}{X_{j c}}=\frac{p_{j} X_{i j}^{k}}{\alpha M_{j}} \quad k=n, m, v \quad i, j=h, f
$$

There are six zero-profit conditions corresponding to the numbers of the four firm types. Given equations (9)-(14), zero profits can be written as the requirement that markup revenues equal fixed costs, with the number of firms as the associated complementary variable.

$$
p_{h} e_{h h}^{n} X_{h h}^{n}+p_{f} e_{h f}^{n} X_{h f}^{n} \leq w_{h} G^{n}+z_{h} F^{n}
$$

$$
p_{f} e_{f f}^{n} X_{f f}^{n}+p_{h} e_{f h}^{n} X_{f h}^{n} \leq w_{f} G^{n}+z_{f} F^{n}
$$

$$
p_{h} e_{h h}^{m} X_{h h}^{m}+p_{f} e_{h f}^{m} X_{h f}^{m} \leq w_{h} G_{1}^{m}+z_{h} F_{1}^{m}+w_{f} G_{2}^{m}+z_{f} F_{2}^{m} \quad\left(m_{h}\right)
$$

$$
p_{f} e_{f f}^{m} X_{f f}^{m}+p_{h} e_{f h}^{m} X_{f h}^{m} \leq w_{f} G_{1}^{m}+z_{f} F_{1}^{m}+w_{h} G_{2}^{m}+z_{h} F_{2}^{m} \quad\left(m_{f}\right)
$$

$$
p_{h} e_{h h}^{v} X_{h h}^{v}+p_{f} e_{h f}^{v} X_{h f}^{v} \leq w_{f} G^{v}+z_{h} F_{1}^{v}+z_{f} F_{2}^{v}
$$

$$
p_{f} e_{f f}^{v} X_{f f}^{v}+p_{h} e_{f h}^{v} X_{f h}^{v} \leq w_{h} G^{v}+z_{f} F_{1}^{v}+z_{h} F_{2}^{v}
$$

Substitute markups into $\mathrm{MR}=\mathrm{MC}$ inequalities

$$
\begin{aligned}
& X \geq \beta M_{i} \frac{p_{i}-w_{i} c}{p_{i}^{2}}, \text { for } X_{i i}^{n}, X_{i i}^{m}, X_{j i}^{v} \\
& X \geq \beta M_{j} \frac{p_{j}-w_{i}(c+\tau)}{p_{j}^{2}}, \text { for } X_{i j}^{n}, X_{j j}^{v}
\end{aligned}
$$

Substitute these inequalities into the zero-profit conditions in order to derive some awful looking 
quadratic equations.

$$
\beta\left[M_{h}\left(\frac{p_{h}-w_{h} c}{p_{h}}\right)^{2}+M_{f}\left(\frac{p_{f}-w_{h}(c+\tau)}{p_{f}}\right)^{2}\right] \leq w_{h} G^{n}+z_{h} F^{n}, \quad\left(n_{h}\right)
$$

$$
\beta\left[M_{h}\left(\frac{p_{h}-w_{f}(c+\tau)}{p_{h}}\right)^{2}+M_{f}\left(\frac{p_{f}-w_{f} c}{p_{f}}\right)^{2}\right] \leq w_{f} G^{n}+z_{f} F^{n}
$$$$
\beta\left[M_{h}\left(\frac{p_{h}-w_{h} c}{p_{h}}\right)^{2}+M_{f}\left(\frac{p_{f}-w_{f} c}{p_{f}}\right)^{2}\right] \leq w_{h} G_{1}^{m}+z_{h} F_{1}^{m}+w_{f} G_{2}^{m}+z_{f} F_{2}^{m}, \quad\left(m_{h}\right)
$$$$
\beta\left[M_{h}\left(\frac{p_{h}-w_{h} c}{p_{h}}\right)^{2}+M_{f}\left(\frac{p_{f}-w_{f} c}{p_{f}}\right)^{2}\right] \leq w_{f} G_{1}^{m}+z_{f} F_{1}^{m}+w_{h} G_{2}^{m}+z_{h} F_{2}^{m}, \quad\left(m_{f}\right)
$$

$$
\beta\left[M_{h}\left(\frac{p_{h}-w_{f}(c+\tau)}{p_{h}}\right)^{2}+M_{f}\left(\frac{p_{f}-w_{f} c}{p_{f}}\right)^{2}\right] \leq w_{f} G^{v}+z_{h} F_{1}^{v}+z_{f} F_{2}^{v}, \quad\left(v_{h}\right)
$$

$$
\beta\left[M_{h}\left(\frac{p_{h}-w_{h} c}{p_{h}}\right)^{2}+M_{f}\left(\frac{p_{f}-w_{h}(c+\tau)}{p_{f}}\right)^{2}\right] \leq w_{h} G^{v}+z_{f} F_{1}^{\nu}+z_{h} F_{2}^{v}, \quad\left(v_{f}\right)
$$

There are several things to note about inequalities (24)-(29) when combined with our earlier assumptions on factor intensities.

(a) Type-m multinationals will have higher markup revenues that type-n or type-v single-plant firms, since the latter bear transport costs.

(b) Type-m multinationals will have higher fixed costs than either a type-n or a type-v firm from at least one country.

(c) Type-m multinationals will tend to dominate when total world income is high $\left(M_{h}+M_{f}\right)$, when trade costs are relatively high $(\tau)$, and when the two countries are relatively symmetric in both incomes and in factor prices.

(d) When total income is low, trade barriers are low, or countries are asymmetric in size or factor prices, then type-v or type-n firms will dominate.

(e) The particular advantage for type-v firms relative to type-n firms lies in situations with unequal factor prices: type-v firms can "arbitrage": locating headquarters activities where skilled labor is cheap and the plant where unskilled labor is cheap. 
Most of these results are relatively obvious when looking at (24)-(29) except perhaps the result that type-m firms are at a disadvantage when the countries are asymmetric in size or in factor prices. Consider first size, and arbitrarily assume that country $h$ is very large relative to $f\left(M_{h}>>\right.$ $M_{f}$ ). Comparing (24) or (29) to (26) or (27), we see that the revenues of a type- $n_{h}$ or type- $v_{f}$ firm converge to those of a type-m firm as $M_{f}$ becomes small, but the type-m firm must pay for costly capacity in the very small market. Thus when countries are very different in size, the equilibrium should be dominated by type-n firms from the large country and/or type-v firms from the small country.

When factor prices are very different between the countries, type-m firms must bear costs in both countries. A type-n firm in one of the countries may then enjoy an advantage by bearing its fixed costs in one country only, or a type-v firm headquartered in one country may enjoy a similar advantage over the two-plant type-m firm. Another way of putting it is that the type-n and type-v firms have an advantage in an asymmetric world by being able to avoid costly capacity in a "bad" (small, costly) market.

\section{Equilibrium Regimes}

As noted in the introduction, we will look at four scenarios. The first is called the "high protection regime" (HP) with trade costs equal to $25 \%$ of marginal production costs and a prohibitive ban on direct investment. Only type $n_{h}$ and $n_{f}$ firms can exist in equilibrium. Second, we look at a trade-liberalization scenario (TL) in which the trade cost falls to zero but the investment ban is retained. Third, this latter scenario is reversed in an investment liberalization case (IL) where the $25 \%$ trade cost remains but there are no restrictions on investment. Four, both restrictions are 
relaxed in the FF scenario. ${ }^{2}$ Solutions to the complementarity problem are computed using Rutherford's MPS/GE solver, now a subsystem of GAMS (Rutherford, 1995a,b). Information on parameter values is give in a short appendix. ${ }^{3}$

Figures 1-4 show Edgeworth factor boxes where the vertical dimension is the world endowment of skilled labor and the horizontal dimension is the world endowment of unskilled labor. The endowment of country h is measured from the southwest (SW) corner and that of country f from the northeast (NE) corner. Figures 1 (HP) and 2 (TL) are unexciting, at least from the point of view of the equilibrium regime. $\mathrm{n}_{\mathrm{h}}$ and $\mathrm{n}_{\mathrm{f}}$ firms exist over most of endowment space (although in greatly varying numbers), except where one country is very small, in which case all firms are located in the large country. Trade liberalization expands the regions of specialization somewhat, consistent with intuition derived from standard factor-proportions models.

Figure 3 (IL) is much more interesting. Removal on the investment ban results in the entry of type-m multinationals over much of parameter space. In the central region, only type-m firms exist in equilibrium consistent with our discussion at the end of the previous section. At other points in which country $h$ is relatively well endowed with skilled labor (points above the SW-NE diagonal) type$m_{h}$ firms are always active except when size differences are extreme. These type- $m_{h}$ firms combine with other firms headquartered in country $\mathrm{h}$ in this region, unless country $\mathrm{h}$ is significantly smaller in which case type- $\mathrm{n}_{\mathrm{f}}$ firms exist in equilibrium as well. In general, firm headquarters are clearly

\footnotetext{
${ }^{2}$ I debated a bit between using a tariff and a transport costs, the latter using real resources (unskilled labor). The difficulty with the former is that the results on real factor prices are difficult to interpret due to optimal tariff effects. Thus I chose the latter. It is more or less equivalent to a situation where all tariff revenue is dissipated in rent seeking (by unskilled workers!) or where the tariff revenue equals the salaries of tariff collectors.

${ }^{3}$ I apologize for having to rely completely on numerical simulation. There are two difficulties: (1) the high dimensionality of the model (47 equations and inequalities), and (2) the questions involve comparative statics on inequalities, something for which our standard economist's tool kit leave us poorly prepared. Some analytical progress on this type of problem was made in Markusen and Venables $(1995,1996 \mathrm{~b})$ at the expense of assuming only four firm types and assuming that all $\mathrm{X}$ sector activities use factors in the same proportion.
} 
concentrated in the country which is skilled-labor abundant.

Figure 4 (FF) presents quite a different picture. Around the SW-NE diagonal there are no multinationals active. Factor prices are equalized or nearly equalization by trade alone and trade is free, so it is not profitable to have a branch plant. When the countries differ fairly significantly in relative endowments, factor-price equalization fails, and so type-v firms can enter, exploiting these differences. Above the SW-NE diagonal type- $v_{h}$ firms are important and indeed dominate when country $\mathrm{h}$ is small. We suspect from these qualitative results alone that trade and investment liberalization are not substitutes, and that the combination of the two together results in a production regime rather different from either alone, at least when the countries differ significantly.

\section{A Special Case}

In this section, I want to look at a special case where one country (h) is large and relatively skilled-labor abundant and country $\mathrm{f}$ is small and skilled-labor scarce. I have in mind situations like NAFTA, where Mexico joined the US and Canada, and the integration of first Southern, and perhaps now Central and Eastern Europe into the EU. Liberalizations in East Asia could eventually follow the same model. The specific case used in the remainder of the paper is as follows:

\section{Parameterization: Country $\mathrm{h}$ three times as large as country $\mathrm{f}$}

$$
(\mathrm{S} / \mathrm{L})_{\mathrm{h}}>2.5^{*}(\mathrm{~S} / \mathrm{L})_{\mathrm{f}}
$$

With reference to Figures $1-4$, the area under consideration is approximately bounded by rows $1-4$ columns 14-15. Results are qualitatively the same for all points in this region. As we can see from Figures 1-4, the equilibrium production regimes are as given below, with production in country $f$ by type- $n_{f}$ firms in HP, no production in TL, production by type- $m_{h}$ in IL, and production by $v_{h}$ in FF. The pattern of trade or "trade regime", is also shown below. "S" denotes service flows, the implicit trade in headquarters services, 
Equilibrium Production Regime

\begin{tabular}{|c|c|c|c|}
\hline$\underline{\mathrm{HP}}$ & $\underline{T L}$ & $\underline{\mathrm{IL}}$ & $\underline{\mathrm{FF}}$ \\
\hline Types $n_{h}, n_{f}$ & Types $n_{h}$ & Type $\mathrm{m}_{\mathrm{h}}, \mathrm{n}_{\mathrm{h}}$ & Types $\mathrm{v}_{\mathrm{h}} \mathrm{n}_{\mathrm{h}}$ \\
\hline$\underline{\mathrm{HP}}$ & $\underline{\mathrm{TL}}$ & $\underline{\text { IL }}$ & $\underline{\mathrm{FF}}$ \\
\hline $\begin{array}{l}\text { export } Y \\
\text { import } X\end{array}$ & $\begin{array}{l}\text { export } Y \\
\text { import } X\end{array}$ & $\begin{array}{l}\text { export } Y \\
\text { import } X, S\end{array}$ & $\begin{array}{l}\text { import } Y, S \\
\text { export } X\end{array}$ \\
\hline
\end{tabular}

$\mathrm{S}$ is measured as the residual between markup revenues earned by foreign-headquartered firms, and fixed costs incurred in the host country by those firms. Alternatively (and identically), $\mathrm{S}$ equals the "merchandise trade imbalance" in equilibrium, the difference between the value of $\mathrm{X}$ exports and $\mathrm{Y}$ imports. One interesting result to note is the reversal in the direction of trade in $\mathrm{X}$ in the FF regime. The vertical type- $v_{h}$ firms dominate production, concentrating headquarters in country $h$ and branch plants in country $\mathrm{f}$. Output is shipped back to country $\mathrm{h}$ in exchange for headquarters' services.

Now consider the output of the $\mathrm{X}$ sector and factor prices under the different scenarios. Figures 5 presents a competitive "parable" for the model. Figure 5 gives the Edgeworth box for country $f$ (not the world), with $S$ on the vertical axis and $L$ on the horizontal axis. Factor allocations to the $\mathrm{X}$ sector are graphed from the SW corner and for $\mathrm{Y}$ from the NE corner. We will first use Figure 5 to discuss the effects of investment liberalization. Suppose that point $A$ is an initial equilibrium in country $\mathrm{f}$ with all $\mathrm{X}$ production by type- $\mathrm{n}_{\mathrm{f}}$ national firms. This implicitly defines an equilibrium factor-price ratio $(w / z)_{0}$

Now liberalize investment, replacing some or even all of the type- $\mathrm{n}_{\mathrm{f}}$ firms with branch plants of type- $m_{h}$ or type- $v_{h}$ firms. First of all, there is a "substitution effect", holding the output of $Y$ constant. This is shown as the movement from A to B in Figure 5. The branch-plants are less skilled-labor intensive than the national firms that they displace because the former do not involve factor demands for skilled-labor-intensive headquarters services. The integrated-firm (type-n) 
isoquant $\mathrm{X}_{0}$ is flatter than the branch-plant isoquant $\mathrm{X}_{0}^{*}$ This substitution effect toward a less skilledlabor-intensive technology would unambiguously increase w/z in country $\mathrm{f}$ : skilled labor experiences at least a relative wage decline.

But there will generally be a "scale effect" as well. The new technology must in some sense be more cost efficient and hence production of $\mathrm{X}$ should expand relative to the initial equilibrium at $\mathrm{A}$. Production could go to point $\mathrm{C}$ in Figure 5 for example, an interesting outcome because relative factor prices are just restored to their initial level at A. Or production might increase even more, to a point like $\mathrm{D}$ where there is a fall in $\mathrm{w} / \mathrm{z}$ relative to $\mathrm{A}$, an increase in the relative wage of skilled labor. If the entering branch plants draw more resources from the $\mathrm{Y}$ sector than from the exiting type- $n_{f}$ firms, then the relative price of skilled labor may rise. Finally, we can complete the parable by noting that we are getting in some sense a "better" technology at points B, C, and D than at point $\mathrm{A}$. Comparing $\mathrm{A}$ and $\mathrm{C}$, note that the relative factor prices are the same, but the two isoquants are drawn from different technologies in effect. Thus the real prices of both $\mathrm{L}$ and $\mathrm{S}$ should be higher at $\mathrm{C}$ than at $\mathrm{A}$, and it is possible that the real wage of unskilled labor a $\mathrm{D}$ is higher than at $\mathrm{A}$ even though the relative wage of unskilled labor has fallen.

Figure 6 shows the approximate actual outcomes for the numerical experiments under the assumptions on country size and relative endowments mentioned earlier. In the initial equilibrium $\mathrm{HP}$, there is some production of $\mathrm{X}$ in country $\mathrm{f}$, and a moderately low $w / z$. Trade liberalization eliminates the type- $\mathrm{n}_{\mathrm{f}}$ firms and all $\mathrm{X}$ production, resulting in an equilibrium at TL, with $\mathrm{w} / \mathrm{z}$ rising ( $w / z$ is monotonic in the slope of the ray from the $\mathrm{Y}$ origin at the NE corner, since $\mathrm{Y}$ is homogeneous of degree one). The investment liberalization regime gives an equilibrium at point IL in Figure 6, with a moderate level of production and the lowest $w / z$ (highest $z / w$ ). The FF equilibrium involves the highest level of $X$ production in country $f$, since the type- $v_{h}$ firms active in this equilibrium are shipping output back to country $h$. w/r lies between its values at HP and IL. 
Table 3 presents the numerical results for the simulation corresponding to Figure 6 . All number have been normalized to 1 in the FF equilibrium for ease of reading. Several ideas suggested in the introduction of the paper are clearly evident. First, trade and investment liberalization are not substitutes for country $\mathrm{f}$ : the two have opposite effects on $\mathrm{X}$ production, the price of skilled labor, the relative price of skilled to unskilled labor within country $\mathrm{f}(\mathrm{z} / \mathrm{w})$, and the skilled-labor wage across the two counties $\left(z_{f} / z_{h}\right)$. Second, FF is not some convex combination of trade and investment liberalization, in the sense of the values of variables in FF lying between their values in TL and IL. While this is true for variables involving $z_{f}$ and $X_{k p}$ it is not true for anyone variable for either country. Third, the (pessimistic) Stolper-Samuelson result that some factor must lose from liberalization is not true in the comparison of HP and FF for either country. All factors experience a real income gain from full liberalization, or at least do not lose. This has to do with the capture of scale economies in the model, increased production efficiency and lower markups with liberalization, effects that are excluded by assumption in the Heckscher-Ohlin model.

Table 3 concludes by ranking some possible policy criteria for country f. The only controversial one would be ranking larger values of $(\mathrm{z} / \mathrm{w})_{\mathrm{f}}$ as a good thing, but $\mathrm{I}$ have in mind a government trying to increase the incentives for workers to acquire skills. Subject to this one arguable choice, we see that for all criteria either FF or IL ranks at the top. Conversely, either HP or TL always ranks at the bottom. Trade liberalization is particularly bad for $\mathrm{X}$ production (important if we added externalities) and for skilled labor (important if it becomes endogenous) in country $f$.

\section{Summary and Conclusions}

The purpose of this paper was to reexamine an old question of the relationship between trade and investment liberalization, with a particular focus on smaller, developing countries and on direct, 
rather than portfolio investment. By direct investment, we mean the provision of skilled-laborintensive producer services (headquarters' services) to foreign production facilities. Physical factors do not flow, consistent with some evidence that multinationals as often as not raise capital in the host country rather than bring it from home.

There are three fairly general results to the paper. First, investment and trade liberalization are not substitutes, in that they often have opposite effects on important variables. Second, investment and trade liberalization together have quite different effects than either alone, including reversing the direction of trade and opposite effects on some factor prices. In a welfare sense, trade and investment liberalization are clearly complements. Third, trade and investment liberalization together may avoid the curse of Stolper-Samuelson, in that the real incomes of all factors can rise in full liberalization, even though the relative price of one factor may fall.

Perhaps the best intuition behind some of these results lies in thinking of knowledge-intensive headquarters services as (potentially) providing a crucial input that is prohibitively costly for a small, skilled-labor-scarce country to develop on its own. An analogy to the present model might be a country that sits on top of huge oil reserves, obviously making it resource abundant. But without the crucial expertise provided by foreign multinationals, the resource lies unexploited or even undiscovered so that the country imports oil under free trade but restricted investment.

Not all of the specific results are robust. The claim of the paper is not to suggest that they are, but rather it has the more modest objective of establishing that the two forms of liberalization may be quite different in the empirically-relevant case of a large, skilled-labor-abundant country liberalizing with a small, skilled-labor-scarce country. ${ }^{4}$

Further work in this area could examine some interesting political-economy implications of

\footnotetext{
${ }^{4} \mathrm{~A}$ example of a result that depends on parameter values is the finding that investment liberalization raises the real wage of skilled labor in both countries. If the countries are not as different in size or in relative endowments as assumed above, then foreign branch-plant entering country $f$ may draw resources primarily from exiting national firms and not from the $\mathrm{Y}$ sector (a movement like A to B in Figure 6). In such a case, the real wage of skilled labor falls as imported producer services substitute for domestic skilled-labor-intensive headquarters' services.
} 
the results, such as the fact that full liberalization raises the real incomes of skilled labor (a powerful class?) in both countries. ${ }^{5}$ At a very casual level, this result appears consistent with the pattern of political support for NAFTA.

$\underline{\text { Table } 3}$

$\begin{array}{lllll}\text { Variable, country } \mathrm{f} & \underline{\mathrm{HP}} & \underline{\mathrm{IL}} & \underline{\mathrm{TL}} & \underline{\mathrm{FF}} \\ \text { Welfare } & 0.90 & 0.94 & 0.99 & 1.00 \\ \text { X production } & 0.16 & 0.49 & 0.00 & 1.00 \\ \mathrm{z} & 0.87 & 1.79 & 0.65 & 1.00 \\ \mathrm{w} & 0.90 & 0.92 & 1.00 & 1.00 \\ \mathrm{z} / \mathrm{w} & 0.97 & 1.95 & 0.64 & 1.00 \\ \mathrm{z} / \mathrm{z}_{\mathrm{h}} & 0.91 & 1.75 & 0.65 & 1.00 \\ \mathrm{w} / \mathrm{w}_{\mathrm{h}} & 0.91 & 0.92 & 1.00 & 1.00 \\ \text { Variable, country h} & \underline{\mathrm{HP}} & \underline{\mathrm{IL}} & \underline{\mathrm{TL}} & \underline{\mathrm{FF}} \\ \text { Welfare } & 1.00 & 0.99 & 1.00 & 1.00 \\ \mathrm{X} \text { production } & 1.26 & 1.14 & 1.39 & 1.00 \\ \mathrm{z} & 0.96 & 0.99 & 0.97 & 1.00 \\ \mathrm{w} & 1.00 & 0.99 & 1.00 & 1.00 \\ \mathrm{z} / \mathrm{w} & 0.96 & 1.00 & 0.97 & 1.00\end{array}$

Country f, Policy Criterion

\begin{tabular}{|c|c|c|c|c|c|c|c|}
\hline Welfare & FF & $>$ & $\mathrm{TL}$ & $>$ & IL & $>$ & HP \\
\hline $\mathrm{X}$ production & $\mathrm{FF}$ & $>$ & IL & $>$ & HP & $>$ & $\mathrm{TL}$ \\
\hline$z$ & IL & $>$ & FF & $>$ & HP & $>$ & TL \\
\hline w & FF & $>$ & $\mathrm{TL}$ & $>$ & IL & $>$ & $\mathrm{HP}$ \\
\hline$z / w$ & IL & $>$ & $\mathrm{FF}$ & $>$ & HP & $>$ & $\mathrm{TL}$ \\
\hline$z_{f} / z_{h}$ & IL & $>$ & $\mathrm{FF}$ & $>$ & HP & $>$ & TL \\
\hline$w_{p} / w_{h}$ & FF & $=$ & $T L$ & $>$ & IL & $>$ & HP \\
\hline
\end{tabular}

\footnotetext{
${ }^{5}$ A similar result is found in Hanson and Feenstra (1995a,b), that investment liberalization may raise the relative wage of skilled labor in both countries. Their model and mine (also an earlier paper with Venables, Markusen and Venables 1996a) share the feature that liberalization results in the transfer to the "south" of activities that are skilled-labor intensive from the south's point of view, but unskilled-labor intensive from the north's point of view.
} 


\section{$\underline{\text { References }}$}

Feenstra, Robert C. and Gordon H. Hanson (1995a), "Foreign Direct Investment and Relative Wages: Evidence from Mexico's Maquiladoras", NBER Working Paper.

Feenstra, Robert C. and Gordon H. Hanson (1995b), "Foreign Investment, Outsourcing, and Relative Wages", NBER Working Paper.

Helpman, Elhanan (1984), "A Simple Theory of Trade with Multinational Corporations", Journal of Political Economy 92, 451-471.

Jones, R. W., I. Coelho and S. Easton (1986), "The Theory of International Factor Flows: the Basic Model", Journal of International Economics 20, 313-327.

Markusen, James R. (1983), "Factor Movements and Commodity Trade as Complements," Journal of International Economics 13, pp. 341-356.

Markusen, James R. (1984), "Multinationals, Multi-Plant Economies, and the Gains from Trade," Journal of International Economics 16, pp. 205-226.

Markusen, James R. and Anthony J. Venables (1995), "Multinational Firms and the New Trade Theory", NBER working paper number 5036.

Markusen, James R. and Anthony J. Venables (1996a), "Multinational Production, Skilled Labor, and Real Wages", in Richard Baldwin and Joseph Francois (editors), Dynamic Issues in Applied Commercial Policy Analysis, Cambridge University Press, forthcoming.

Markusen, James R. and Anthony J. Venables (1996b), "The Theory of Endowment, Intra-Industry, and Multinational Trade", NBER working paper 5529.

Mundell, Robert (1957), "International Trade and Factor Mobility", American Economic Review 47, 321-335.

Neary, J. Peter (1995), "Factor Mobility and International Trade", Canadian Journal of Economics 28, S4-S23.

OECD (1996), "Evidence on Trade and Wages in the Developing World", Development Centre Technical Paper, number 119.

Rutherford, Thomas F. (1995a), "Applied General-Equilibrium Modelling with MPS/GE as a GAMS Subsystem".

Rutherford, Thomas F. (1995b), "Extensions of GAMS for Complementarity Problems Arising in Applied Economics", Journal of Economic Dynamics and Control.

Slaughter, Matthew J. (1995), "Multinational Corporations, Outsourcing, and American Relative Wage Divergence", NBER working paper no. 5253.

Wong, Kar-Yui (1986), "Are International Trade and Factor Mobility Substitutes?", Journal of International Economics, 25-44. 
Appendix - numerical values

Attaching numerical values to factor intensities for firm types and production activities is tricky, because they depend on factor prices. Factor prices in an equilibrium in which only type-m firms are active will differ from factor prices in an equilibrium in which only type-n firms active for example. This makes comparisons imprecise. But the variations due to factor-price changes are not large, so I present here some values. Countries are identical (the center of the world Edgeworth box) and values for type-m firms are from the IL scenario (Figure 3) and values for type-n firms are from the TL/FF scenario (Figure 4).

Factor intensity ratio (S/L) for type-m firms:

(calculated at the IL equilibrium)

Factor intensity ratio (S/L) for type-n firms:

(calculated at the TL equilibrium)

Factor endowment ratio $(\overline{\mathrm{S}} / \overline{\mathrm{L}})$ :

(countries identical)

Factor intensity ratio (S/L) for branch plants:

(calculated at the IL equilibrium)

Factor intensity ratio (S/L) for composite $\mathrm{Y}$ sector:

0.55 (average of the values at the IL and TL equilibria)

Ratio of two-plant (type-m) to one-plant (type-n or v) fixed costs 1.71 (numerator at the IL eq., denominator at the TL eq.)

\section{$\underline{\text { Some other values }}$}

Elasticity of substitution in $\mathrm{Y}$

3

Approximate number of firms active in equilibrium

8

Approximate markups

Approximate factor-price ratio $\mathrm{z} / \mathrm{w}$

Distribution of fixed cost requirements for type- $n_{h}$ firms

$\mathrm{S}_{\mathbf{h}}$

$\mathrm{L}_{\mathrm{h}}$

Distribution of fixed cost requirements for type- $m_{h}$ firms

$$
\begin{aligned}
& S_{h}+S_{f} \\
& L_{h}+L_{f}
\end{aligned}
$$

Distribution of fixed cost requirements for type- $\mathrm{v}_{\mathrm{h}}$ firms ${ }^{*}$

$$
\mathrm{S}_{\mathrm{h}}+\mathrm{S}_{\mathrm{f}}
$$

"In the computations, the fixed costs for type-v firms are actually raised by $0.1 \%$, in order to prevent degeneracy of the model in certain cases. If such an assumption is not made then, for example, an equilibrium with $n_{h}=n_{f}=4$ implies that $v_{h}=v_{f}=4$ is also an equilibrium. This is thus a "tie-break" rule, in favor of type-n firms over type-v firms (i.e., the latter suffer a small penalty for splitting their plant and headquarters). 
Figure 1: High Protection Regime

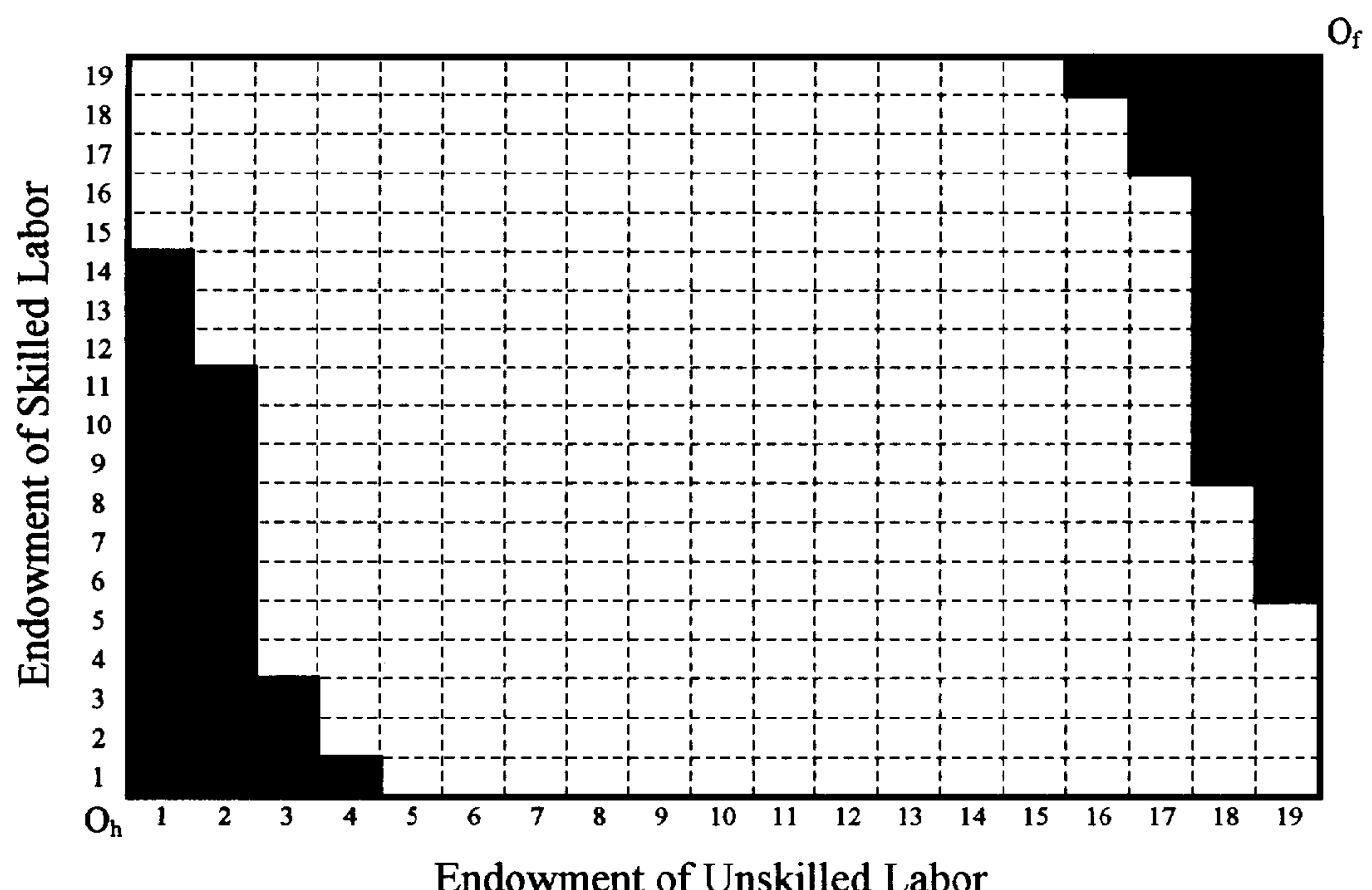

Figure 2: Trade Liberalization Regime

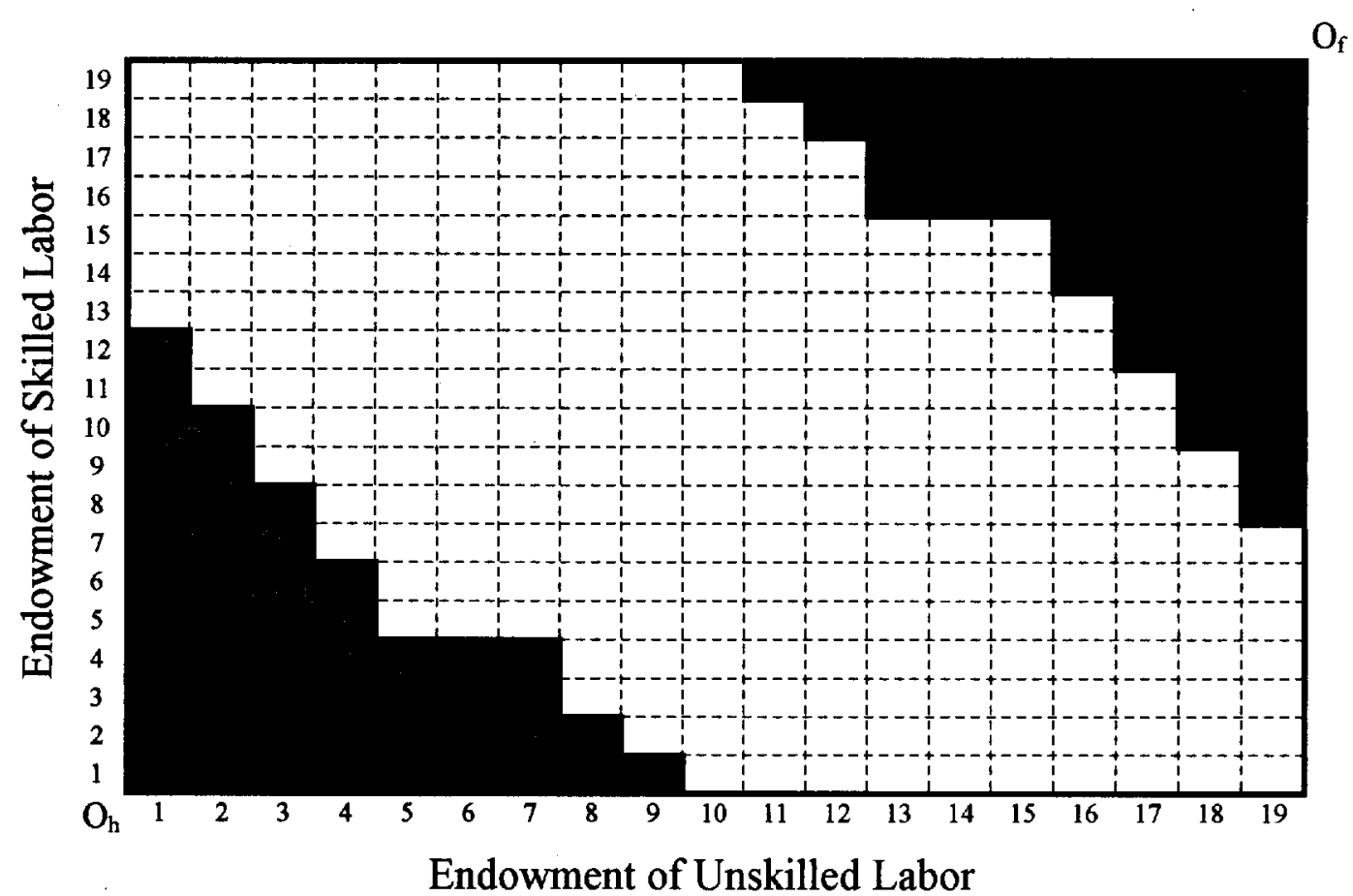

nh, nf firms

nf firms (SW corner), nh firms (NE corner) 


\section{Figure 3: Investment Liberalization Regime}

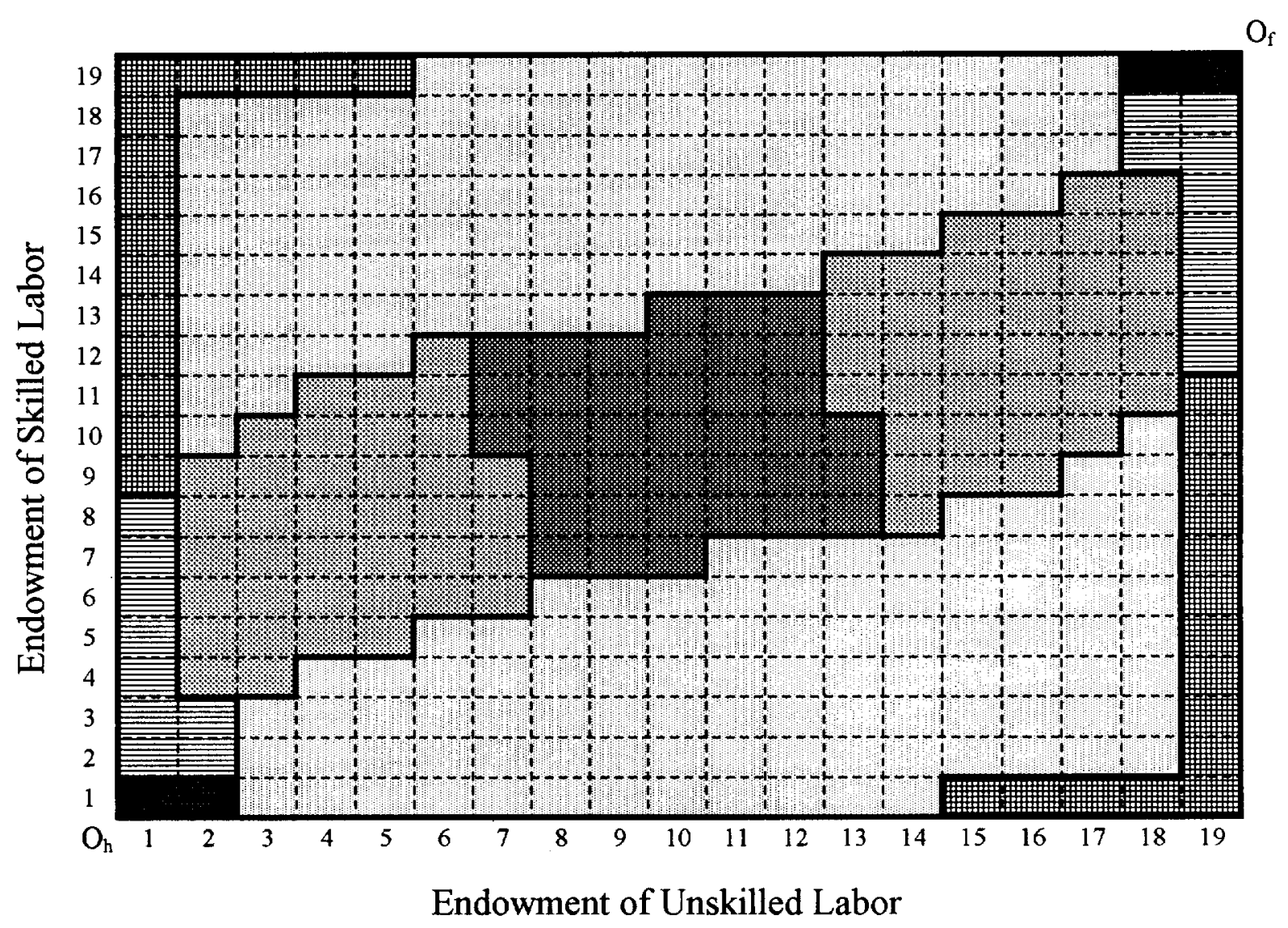

Above SW-NE Diagonal

vh; . vh,nh

$\mathrm{mh}$; mh,vh; mh,nh; mh,vh,nh

mh,nf; mh,nf,vh; mh,nf,mf

vh,nf

nh
Below SW-NE Diagonal

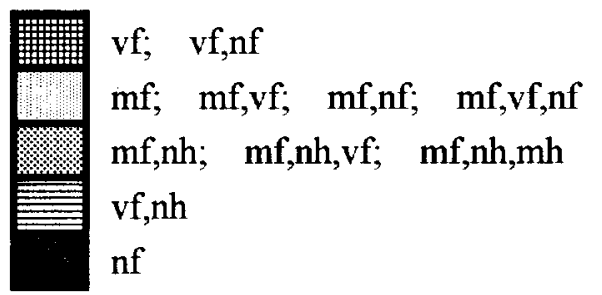

$\mathrm{mh}, \mathrm{mf}$

In these regions (above diagonal), all firms are headquartered in country $\mathrm{h}$ 


\section{Figure 4: Trade and Investment Liberalized (FF)}

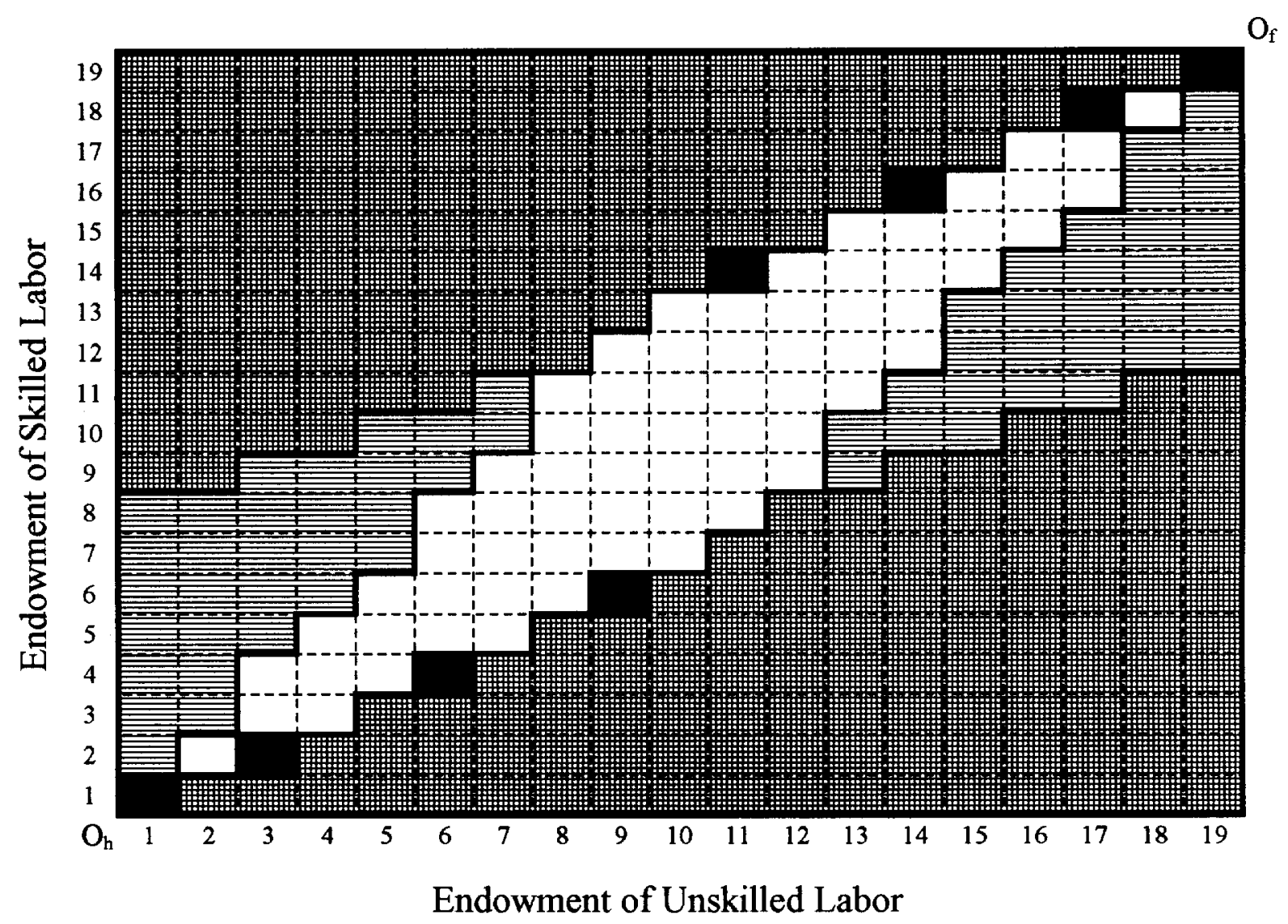

Above SW-NE Diagonal

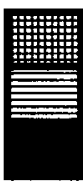

vh; vh,nh

vh,nf; vh,nf,nh

nh
Below SW-NE Diagonal

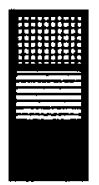

vf; $\quad$ vf,nf

vf,nh; vf,nh,nf

$\mathrm{nf}$

nh, nf 
Figure 5: Substitution and Scale Effects on Factor Prices

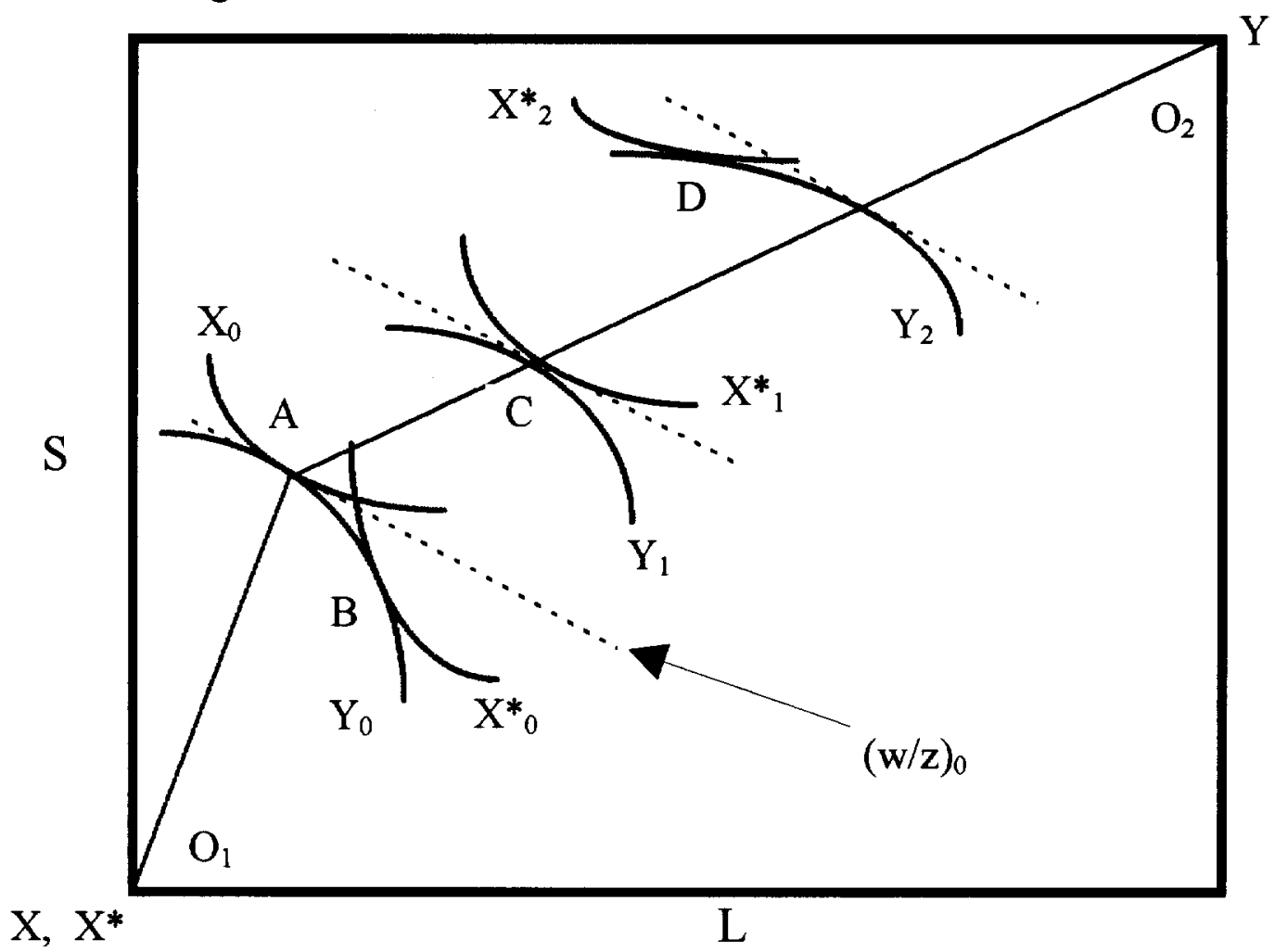

Figure 6: Factor Allocations in Different Outcomes

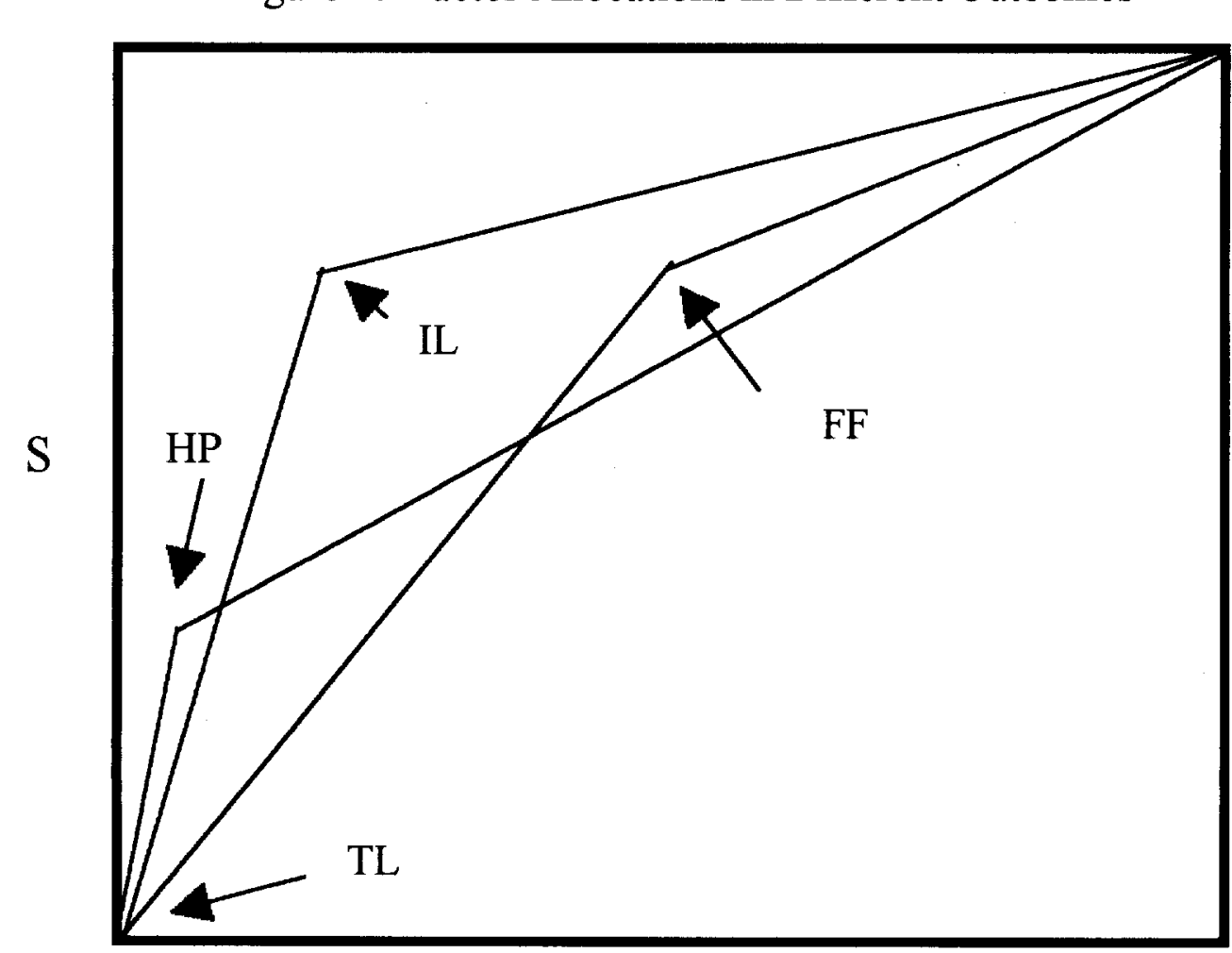

$\mathrm{X}, \mathrm{X}^{*}$

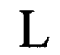

$\mathrm{X}$ - production in plants of local type-n firms
$\mathrm{X}^{*}$ - production in plants of foreign-owned firms 